\title{
Activities of Regulatory Enzymes in Alkane-utilizing and Lipid-accumulating Yeasts and Moulds
}

\author{
By D. A. WHITWORTH AND C. RATLEDGE \\ Department of Biochemistry, The University, Hull HU6 $7 R X$
}

(Received 2I March 1975; revised 8 May 1975)

INTRODUCTION

Investigations with yeasts and moulds which accumulate up to $60 \%$ of their dry weight as lipid, mainly triglycerides, have been primarily concerned with the quantity and quality of lipid produced by different species. The few studies on the intermediary metabolism of these micro-organisms have been confined mainly to species of Rhodotorula and Candida. Brady \& Chambliss (1967) and Höfer et al. (1969) demonstrated that phosphofructokinase was absent in all the species of Rhodotorula they examined. Barbalace, Chambliss \& Brady (I97I) showed that pyruva tekinase from Rhodotorula glutinis and other oxidative yeasts was not only insensitive to activation but its inhibition by ATP could not be relieved by fructose I,6-diphosphate. The enzyme from $R$. gracilis, however, was activated by fructose 1,6diphosphate (Höfer, Betz \& Becker, 1970). Höfer et al. (I97I) later showed that the pentose phosphate pathway was the predominant mechanism for carbohydrate metabolism in those yeasts lacking phosphofructokinase.

Observations with Candida 107, a lipid-accumulating, alkane-utilizing yeast, similar to Rhodotorula in possessing enzymes of the pentose pathway and lacking phosphofructokinase (Whitworth \& Ratledge, 1975), led us to investigate whether the activities of regulatory enzymes of the pentose phosphate and glycolytic pathways are similar throughout lipid-accumulating or alkane-utilizing micro-organisms.

\section{METHODS}

Organisms and growth. All micro-organisms (see Table I) were grown on glucose-limiting medium (Whitworth \& Ratledge, 1975). All the strains of Candida are able to utilize alkanes but were not grown on them in this work. All the organisms except Saccharomyces carlsbergensis, Candida lipolytica and C. tropicalis accumulate lipid; lipid-accumulating organisms were selected from lists given in the reviews of Woodbine (1959) and Whitworth \& Ratledge (1974). Candida 107 was grown in continuous culture at a dilution rate of $0.15 \mathrm{~h}^{-1}$; other yeasts were grown in shake flasks and harvested in the exponential phase (20 to $24 \mathrm{~h}$ ). Moulds were grown in vortex-aerated, I 1 vessels and also harvested in the exponential phase (after 40 to $48 \mathrm{~h}$ ). All organisms were grown at $30{ }^{\circ} \mathrm{C}$ except for the two species of Rhodotorula which were grown at $25^{\circ} \mathrm{C}$.

Preparation of cell-free extracts and enzyme assays. Organisms were harvested by centrifuging, then washed and resuspended in $50 \mathrm{mM}$-phosphate buffer $\mathrm{pH} 7.5$ containing I mM$\mathrm{MgCl}_{2}$, to give $0.3 \mathrm{~g}$ packed mass $/ \mathrm{ml}$ for yeast and $\mathrm{I} \cdot 0 \mathrm{~g} / \mathrm{ml}$ for mycelial fungi. Organisms were disrupted by a single passage through a French press at $35 \mathrm{MPa}$. The homogenate was centrifuged at $40000 \mathrm{~g}$ for $30 \mathrm{~min}$ and the precipitate discarded. The protein concentration of the supernatant solution was adjusted to $10 \mathrm{mg} / \mathrm{ml}$. Enzymes assays (Whitworth \& 
Table I. Enzyme activities of some lipid-accumulating organisms

Enzyme activities were determined on extracts after centrifuging at $40000 \mathrm{~g}$ for $30 \mathrm{~min}$. Values quoted are the averages of at least two determinations.

\begin{tabular}{|c|c|c|c|c|c|}
\hline \multirow[b]{2}{*}{ Micro-organisms } & \multicolumn{5}{|c|}{ Enzyme activities $(\mathrm{nmol} / \mathrm{mg}$ of protein $/ \mathrm{min}$ ) } \\
\hline & $\begin{array}{c}\text { Glucose } \\
\text { 6-phosphate } \\
\text { dehydrogenase }\end{array}$ & $\begin{array}{l}\text { 6-Phospho- } \\
\text { gluconate de- } \\
\text { hydrogenase }\end{array}$ & $\begin{array}{l}\text { Phospho- } \\
\text { fructo- } \\
\text { kinase }\end{array}$ & $\begin{array}{l}\text { Fructose- } \\
\text { I,6-disphos- } \\
\text { phatase }\end{array}$ & $\begin{array}{c}\text { Pyruvate } \\
\text { kinase }\end{array}$ \\
\hline $\begin{array}{l}\text { Saccharomyces carlsbergensis } \\
\text { (NCYC530) }\end{array}$ & 129 & 65 & 194 & 5 & 8 \\
\hline Candida lipolytica (ATCC866I) & 290 & I6I & 194 & 13 & 323 \\
\hline Candida lipolytica (NCYCI 53) & 565 & 403 & 400 & 16 & 323 \\
\hline Candida tropicalis ( $\left.\mathrm{NCYC}_{4}\right)$ & 290 & 129 & 0 & 13 & 581 \\
\hline Candida 107 & 516 & 516 & 0 & 10 & I94 \\
\hline Hansenula anomola ( $\mathrm{NCYC1} 8)$ & 290 & 226 & 323 & 10 & 215 \\
\hline Rhotodorula glutinis ( $\mathrm{NCYC} 59$ ) & 194 & 194 & 0 & o & 258 \\
\hline Rhodotorula graminis ( $\mathrm{NCYC502)}$ & 226 & $16 \mathrm{I}$ & 0 & 0 & 160 \\
\hline Lipomyces starkeyi (NCYC533) & I6I & 194 & 226 & 3 & 20 \\
\hline $\begin{array}{l}\text { Geotrichium candidum } \\
\text { (IMI233I2) }\end{array}$ & 258 & I6I & I6I & 3 & 420 \\
\hline $\begin{array}{l}\text { Fusarium oxysporium } \\
\text { (IMII4I I40) }\end{array}$ & 0 & o & 31 & o & 580 \\
\hline Penicillium spinulosa (Iм174803) & 323 & 194 & 65 & o & 450 \\
\hline Mucor javanicus (IMI25330) & 263 & 107 & 86 & o & 540 \\
\hline
\end{tabular}

Ratledge, 1975) were completed within $7 \mathrm{~h}$ of harvesting the micro-organisms. All assays were carried out on at least two different preparations of cell extract. If there was a significant difference between these results, further assays were carried out to establish correct values.

Chemicals. All enzyme substrates and co-factors were from Sigma, except sodium citrate which was from Fisons Ltd, Loughborough.

\section{RESULTS}

Depending on the activity of the enzyme, normally 0.02 to I $\mathrm{mg}$ protein was used in $\mathrm{x} \mathrm{ml}$ of each assay mixture. The absence of glucose 6-phosphate dehydrogenase and 6phosphogluconate dehydrogenase in Fusarium oxysporum was confirmed with three different extract preparations and also by an examination of activity in the centrifuged particulate material. After determining the activities of all the enzymes in the absence of potential metabolic regulators (Table I) we examined the effect of different concentrations of the following metabolites on each enzyme from all 13 organisms. The same preparation was used for all determinations to minimize variations in results.

Effect of NADPH. When added at concentrations greater than 0.6 to $0.7 \mathrm{~mm}$, NADPH completely inhibited activity of all preparations of glucose 6-phosphate dehydrogenase and 6-phosphogluconate dehydrogenase. Its effect on the other enzymes was not investigated.

Effect of citrate. Citrate, at Io mM, had little effect on glucose 6-phosphate dehydrogenase or 6-phosphogluconate dehydrogenase from any source and inhibition never exceeded $20 \%$. With phosphofructokinase, Io mM-citrate usually resulted in up to $30 \%$ inhibition, but in some lipid-accumulating micro-organisms strong inhibition was observed: the enzyme from Hansenula anomola was inhibited $80 \%$ by 10 mM-citrate, and that from $F$. oxysporium, though only present at low concentrations, was completely inhibited by 2 mM-citrate. 
Pyruvate kinase from the lipid-accumulating yeasts and moulds was more susceptible to citrate inhibition than that from other sources: with Io mM-citrate, a 60 to $80 \%$ decrease in activity occurred with the enzyme from $H$. anomola, Rhodotorula graminis, Lipomyces starkeyi, Mucor javanicus and $F$. oxysporium. However, the enzyme from the latter organism was, in fact, activated by $50 \%$ with 2 mM-citrate. In the other micro-organisms there was little $(<20 \%)$ or no inhibition with citrate up to Io mM.

Effect of phosphoenolpyruvate. Glucose 6-phosphate dehydrogenase and 6-phosphogluconate dehydrogenase were never inhibited by phosphoenolpyruvate by more than 20 to $30 \%$. The effect of this metabolite was not examined with the other enzymes.

Effect of ATP. ATP at 2 to Io mM resulted in many extensive inhibitory effects. Although not strongly affecting glucose 6-phosphate dehydrogenase, Io mM-ATP with 6-phosphogluconate dehydrogenase from both strains of C. lipolytica, R. graminis, L. starkeyi and Penicillium spinulosa resulted in $40 \%$ inhibition. With $\mathrm{H}$. anomola, $100 \%$ inhibition was observed with ATP at this concentration. With phosphofructokinase from $C$. lipolytica ATCC866I, Saccharomyces carlsbergensis, L. starkeyi, F. oxysporium and M. javanicus, ATP at $2 \mathrm{mM}$ produced 50 to $80 \%$ inhibition, whilst similar inhibitions occurred with the same enzyme from $C$. lipolytica $\mathrm{NCYCI} 53$ and $H$. anomola only with ATP at Io mM. ATP did not appear to inhibit significantly the enzyme from Geotrichium candidum or P. spinulosa. With pyruvate kinase, ATP at Io mM was normally inhibitory: it produced $40 \%$ inhibition of the enzyme from both Rhodotorulas, $50 \%$ inhibition with $\mathrm{H}$. anomola, $60 \%$ with $\mathrm{L}$. starkeyi and G. candidum, and more than $90 \%$ with Candida 107, C. tropicalis, both $C$. lipolytica strains and with $M$. javanicus. There was little inhibitory effect on the enzyme from $F$. oxysporium, $S$. carlsbergensis and $P$. spinulosa; however, 2 mM-ATP activated the enzyme from $F$. oxysporium by $50 \%$.

Effect of fructose 1,6-diphosphate. Pyruvate kinase, which was assayed at $\mathrm{pH} 7 \cdot 5$, was activated in all cases (except Candida 107 and both Rhodotorula species), with 5 mM-fructose 1,6-diphosphate by 20 to $30 \%$, though in C. tropicalis and L. starkeyi the enzyme was activated by $50 \%$. This effect could relieve, either completely or partially, the inhibition brought about by Io mM-ATP.

\section{DISCUSSION}

Although our results are probably quantitatively different from those pertaining in vivo, they nevertheless should provide a guide as to the likely patterns of control with each organism. For alkane-utilizing micro-organisms no special common features could be distinguished, except possibly the occurrence of a slightly higher activity of fructose-I,6bisphosphatase. This enzyme does indeed increase in activity following growth of Candida I07 on alkanes (Whitworth \& Ratledge, 1975) although $n$-alkanes were never used as substrate in these present experiments. With lipid-accumulating micro-organisms there probably is the absence of some strategic regulatory point to allow the system to run 'out of control' and thus lead to an excessive accumulation of lipid. Although lipid production may be viewed as a means of disposing of excessive quantities of $\mathrm{NAD}(\mathrm{P}) \mathrm{H}$, as in some bacteria producing poly- $\beta$-hydroxybutyrate (Senior \& Dawes, 1971), this still leaves unanswered why such an excess of reducing power should be produced in the first place. With Candida 107 and the Rhodotorula species an 'out of control' situation is achieved by the absence of phosphofructokinase, which in other organisms is regulated by feedback inhibition by ATP, citrate and phosphoenolpyruvate. However, this enzyme was also absent from C. tropicalis, which is not a lipid-accumulating yeast and, moreover, was present in all the other lipidaccumulating micro-organisms examined. On the other hand, with G. candidum and 
$P$. spinulosum this enzyme did not demonstrate allosteric inhibition by citrate or ATP and therefore would not be able to regulate glycolysis and the rate of entry of carbon into the acetyl-CoA pool and thence into fatty acids. How similar metabolic 'short circuits' are achieved in $H$. anomola, $L$. starkeyi, $F$. oxysporium and $M$. javanicus is not apparent. In these organisms other enzymes, not examined here, may serve to maintain intracellular concentrations of the potential feedback-inhibitors lower than were found to be effective in these in vivo assay systems.

The possession of an efficient pentose phosphate cycle, as the progenitor of NADPH, is also not a prerequisite for lipid accumulation. In $F$. oxysporium, which can accumulate 25 to $34 \%$ of its cell dry weight as lipid (Woodbine, Gregory \& Walker, I95I), the pentose phosphate cycle appeared completely absent. How this organism produces NADPH at a sufficiently rapid rate to sustain fatty acid synthesis is unknown. In all the other lipidaccumulating strains the pentose cycle, as manifested by the activities of glucose 6-phosphate dehydrogenase and 6-phosphogluconate dehydrogenase, was much in evidence, but so too was it in the other yeasts examined.

Thus, although all the organisms showed individual variations in the patterns of control over glycolysis, it was not always possible to explain why a particular species was, or was not, capable of lipid accumulation. With Candida 107, the Rhodotorula species, G. candidum and $P$. spinulosa, the reasons are perhaps obvious. Further work is needed with the other organisms, however, before our proposal that lipid-accumulation depends upon a strategic control point being absent, can be considered of general applicability.

D.A.W. thanks the Science Research Council for a postdoctoral fellowship under grant B/RG/5391.9 in support of this work. We thank Miss S. Richards for her technical assistance.

\section{REFERENCES}

Barbalace, D. S., Chambliss, G. H. \& Brady, R. J. (I97I). Some differences in pyruvate kinase regulation in selected yeasts. Biochemical and Biophysical Research Communications 42, 287-29I.

Brady, R. J. \& Chambliss, G. H. (1967). The lack of phosphofructokinase activity in several species of Rhodotorula. Biochemical and Biophysical Research Communications 29, 898-903.

Höfer, M., Becker, J.-U., Brand, K., Deckner, K. \& Betz, A. (I969). A study of the enzyme equipment of the yeast Rhodotorula gracilis. FEBS Letters 3, 322-324.

Höfer, M., Betz, A. \& BeCKer, J.-U. (1970). Metabolism of the obligatory aerobic yeast Rhodotorula gracilis. I. Changes in metabolite concentrations following D-glucose and D-xylose addition to the cell suspension. Archiv für Mikrobiologie 71, 99-1 10.

Höfer, M., Brand, K., DeCKNeR, K. \& Becker, J.-U. (197I). Importance of the pentose phosphate pathway for D-glucose catabolism in the obligatory aerobic yeast Rhodotorula gracilis. Biochemical Journal 123, $855-863$.

SENioR, P. J. \& DAWES, E. A. (I97I). Poly- $\beta$-hydroxybutyrate biosynthesis and the regulation of glucose metabolism in Azotobacter beijerinckii. Biochemical Journal 125, 55-66.

Whitworth, D. A. \& Ratledge, C. (1974). Micro-organisms as a potential source of oils and fats. Process Biochemistry 9, (9) I4-22.

Whitworth, D. A. \& RATledGe, C. (1975). An analysis of intermediary metabolism and its control in a fat synthesizing yeast (Candida 107) growing on glucose or alkanes. Journal of General Microbiology 88, $275-288$.

Woodbine, M. (1959). Microbial fat: micro-organisms as a potential fat producer. In Progress in Industrial Microbiology, vol. I, pp. I8I-245. Edited by D. J. D. Hockenhull. London: Heywood.

Woodbine, M., Gregory, M. E. \& Walker, T. K. (I95I). Microbiological synthesis of fat. Preliminary survey of the fat-producing moulds. Journal of Experimental Botany 2, 204-2 I I. 